\title{
Kapabilitas Dinamis, Implementasi Sistem Akuntansi Pemerintahan dan Kualitas Laporan Keuangan SKPD (Studi pada Pemerintah Kabupaten Kediri)
}

\author{
Yohanes P. Bondan S. ${ }^{*}$, Ali Djamhuri ${ }^{1}$, Rosidi ${ }^{1}$ \\ ${ }^{1}$ Fakultas Ekonomi dan Bisnis Universitas Brawijaya Malang \\ *Penulis korespondensi; Surel: jipibis@gmail.com
}

\begin{abstract}
ABSTRAK
Penelitian ini bertujuan untuk menguji pengaruh konstruk kapabilitas dinamis organisasi dan kontribusi masing-masing dimensinya terhadap implementasi Sistem Akuntansi Pemerintahan (SAP) berbasis akrual dan dampak implementasi SAP terhadap kualitas laporan keuangan yang dihasilkan Satuan Kerja Perangkat Daerah (SKPD) Kabupaten Kediri. Dimensi kapabilitas dinamis yang digunakan dalam penelitian ini meliputi kapabilitas penginderaan, kapabilitas belajar, kapabilitas integrasi, dan kapabilitas koordinasi. Metode penelitian yang digunakan adalah penelitian kuantitatif-eksplanatif dengan sasaran penelitian meliputi para Pejabat Penatausaha Keuangan (PPK) dan pegawai yang membantu PPK secara langsung dalam pekerjaan akuntansi SKPD. Survei dilaksanakan pada 32 SKPD dan datanya dianalisis secara statistik dengan Structural Equation Modeling (SEM). Hasil penelitian menunjukkan bahwa konstruk kapabilitas dinamis berpengaruh terhadap implementasi SAP. Dimensi yang paling berkontribusi dalam membentuk kapabilitas dinamis adalah kapabilitas integrasi yang kemudian disusul dengan kapabilitas koordinasi, kapabilitas belajar, dan kapabilitas penginderaan. Penelitian juga membuktikan bahwa implementasi SAP berpengaruh terhadap kualitas laporan keuangan.
\end{abstract}

Kata kunci: Kapabilitas dinamis; kualitas laporan keuangan; Standar Akuntansi Pemerintahan.

\begin{abstract}
This research aims to examine the influence of organization's dynamic capability construct and each of its dimensions on the implementation of accrual-based Government Accounting Standard (GAS) and the impact of such implementation on the financial statement quality produced by Regional Work Units of Kediri District. The dynamic capability dimensions used in this study are sensing, learning, integrating, and coordinating capabilities. The quantitative-explanatory research approach is applied. Unit analysis of this study is financial administration officers and the assisting staffs being in charge of the Regional Work Units' accounting work. Survey conducted in 32 Regional Work Units and the data were analysed using Structural Equation Modeling (SEM). The result of the analysis shows that dynamic capability construct influences the GAS implementation. The most significant dimension that shape the dynamic capability is integrating capability, following by coordinating capability, learning capability, and sensing capability. The research also demonstrates that the implementation of the GAS affects the quality of financial statement.
\end{abstract}

Keywords: Dynamic capability; Government Accounting Standard; quality of financial statement.

\section{PENDAHULUAN}

Kualitas laporan keuangan di sektor pemerintahan mendapatkan fokus perhatian global yang semakin besar akhir-akhir ini seiring dengan kegagalan ekonomi Yunani yang berdampak luas terhadap negara-negara di Uni-Eropa, Amerika, dan Asia. George Serafeim, seorang profesor dari sekolah bisnis Harvard, yang dikutip dalam Akuntan Indonesia (2015) menyebut krisis utang di negeri para dewa tersebut dipicu karena kurangnya informasi keuangan yang berkualitas sehing- 
ga menyebabkan terjadinya pengambilan keputusan yang buruk dalam pengelolaan keuangan negara.

Motivasi untuk meningkatkan kualitas pelaporan keuangan juga menjadi perhatian bagi pemerintah Indonesia. Pencapaian tujuan tersebut menjadi salah satu pendorong bagi penggunaan Standar Akuntansi Pemerintahan (SAP) dengan basis akrual di Indonesia, terlepas dari berbagai kontroversi adanya intervensi pihak eksternal yang mempengaruhi. SAP berbasis akrual dipandang dapat memberikan manfaat yang lebih banyak bagi para pemangku kepentingan dibandingkan dengan biaya yang dikeluarkan (KSAP 2010). Oleh karena itu Pemerintah Indonesia menetapkan bahwa basis akuntansi akrual harus diterapkan oleh pemerintah pusat maupun daerah paling lambat pada tahun 2015 sesuai Permenkeu No. 270/PMK.05/2014 tentang penerapan Standar Akuntansi Pemerintahan berbasis akrual pada pemerintah pusat dan Permendagri 64 Tahun 2013 tentang penerapan standar akuntansi pemerintahan berbasis akrual pada pemerintah daerah.

Penerapan akuntansi berbasis akrual pada pemerintah Kabupaten Kediri di tahun 2015 menghasilkan kualitas laporan keuangan yang belum memuaskan. Hasil pemeriksaan Laporan Keuangan Pemerintah Daerah oleh Badan Pemeriksa Keuangan menghasilkan opini wajar dengan pengecualian. Pengecualian tersebut disebabkan karena kurang lengkap dan tidak diterapkannya dengan baik Peraturan Bupati Kediri Nomor 33 Tahun 2015 tentang Kebijakan Akuntansi Pemerintah Kabupaten Kediri. Semua pengecualian tersebut berkontribusi pada potensi kerugian yang signifikan sebagaimana tampak dalam Tabel 1 . Permasalahan tersebut menggambarkan bahwa implementasi SAP pada tingkat SKPD masih menghadapi berbagai kendala, padahal implementasi SAP yang baik merupakan faktor yang sangat berpengaruh untuk meningkatkan kualitas laporan keuangan. Pengaruh positif implementasi SAP terhadap kualitas laporan keuangan pada tingkat Pemerintah Daerah ini dibuktikan oleh penelitian empiris yang dilakukan oleh beberapa peneliti seperti Nugraheni \& Subaweh (2008), Juwita (2013), Munasyir (2015).

Juwita (2013), meneliti pengaruh implementasi SAP dan Sistem Informasi Akuntansi Terhadap Kualitas Laporan Keuangan. Studi dilakukan pada seluruh Pemerintah Kota/Kabupaten di Provinsi Jawa Barat. Hasil penelitian menunjukan bahwa implementasi SAP dan implementasi sistem informasi akuntansi memiliki hubungan yang sangat kuat dengan kualitas laporan keuangan. Nugraheni \& Subaweh (2008) melakukan penelitian untuk menguji hubungan antara penerapan SAP dan kualitas laporan keuangan. Penelitian studi kasus ini dilakukan pada Inspektorat Jenderal Departemen Pendidikan Nasional. Hasil penelitian menunjukkan bahwa terdapat pengaruh positif penerapan SAP terhadap peningkatan kualitas laporan keuangan. Penelitian senada dilakukan oleh Munasyir (2015) untuk menguji pengaruh implementasi SAP dan Sistem Informasi Akuntansi terhadap Kualitas Laporan Keuangan di SKPD Kabupaten Aceh Utara. Kesimpulan yang didapat adalah bahwa implementasi SAP dan sistem informasi akuntansi baik secara parsial maupun simultan memiliki hubungan positif yang kuat terhadap kualitas laporan keuangan.

Karakteristik sektor publik yang memiliki keterbatasan akses terhadap sumber daya (Pablo et al. 2007) menyebabkan akumulasi sumber daya strategis bukan satu-satunya faktor yang harus diperhatikan agar implementasi SAP dapat berjalan optimal. Kesuksesan penerapan akuntansi berbasis akrual harus lebih didasarkan pada kapabilitas organisasi dalam merubah dan mengombinasikan ulang sumber daya yang ada untuk mencapai perubahan yang diharapkan. Kapabilitas dinamis menjadi kunci yang harus diperhatikan agar Pemerintah Daerah dapat mengelola perubahan standar akuntansi dengan baik dan menghasilkan kualitas laporan keuangan yang prima.

Konsep kapabilitas dinamis dapat menjelaskan bagaimana sekelompok sumber daya yang dimiliki oleh suatu organisasi dapat disusun dan dikombinasikan ulang untuk menyelaraskan

Tabel 1. Rincian Pengecualian atas Opini Wajar LKPD Kabupaten Kediri Tahun 2015

\begin{tabular}{|c|c|c|c|}
\hline Sebab Pengecuali-an & SKPD & Ket & Potensi Kerugian \\
\hline $\begin{array}{l}\text { Tidak diterapkan kebijakan } \\
\text { pencatatan, penyajian, dan } \\
\text { pengungkap-an aset tetap. }\end{array}$ & $\begin{array}{l}\text { Dinas Kebersihan dan } \\
\text { Pertamanan. }\end{array}$ & $\begin{array}{l}\text { PJU disajikan sebanyak } 4.511 \text { Unit } \\
\text { PJU tidak disajikan sebanyak } \\
40.026 \text { Unit }\end{array}$ & \pm Ratusan Milyar \\
\hline $\begin{array}{l}\text { Belum ada kebijakan akuntansi atas } \\
\text { pendapatan hibah yang diterma } \\
\text { langsung oleh SKPD. }\end{array}$ & $\begin{array}{l}\text { Dinas Pendidikan, } \\
\text { Pemuda dan Olah } \\
\text { Raga. }\end{array}$ & $\begin{array}{l}\text { BOS disajikan sebesar selisih } \\
\text { penerimaan dan pengeluaran } \\
\text { BOS tidak disajikan saldo awal } \\
\text { Tidak disajikan pendapatan bunga }\end{array}$ & $\begin{array}{l} \pm \text { Puluhan } ~ \\
\text { Ratusan Milyar }\end{array}$ \\
\hline
\end{tabular}

Sumber: BPK (2016), diolah 
dengan perubahan yang terjadi ( Proeller, Proeller, Kroll, Krause, \& Vogel 2014). Kapabilitas dinamis merupakan perilaku organisasi yang selalu berupaya untuk mengintegrasikan, membentuk ulang, memperbarui dan menciptakan kembali rutinitas operasionalnya dalam upaya merespon perubahan lingkungan (Helfat et al. 2007; Wang \& Ahmed 2007).

Konsep kapabilitas dinamis merupakan konsep yang abstrak, namun pada dasarnya terdiri atas kebiasaan-kebiasaan tertentu yang dapat diidentifikasi (Eisenhardt \& Martin 2000). Berdasarkan pemahaman tersebut, para ahli dan peneliti kemudian membuat model agar kapabilitas dinamis dapat diukur melalui indentifikasi dimensi-dimensi yang menyusunnya. Salah satunya adalah Pavlou \& Sawy (2011) yang mengklasifikasi kapabilitas dinamis dalam dimensidimensi kapabilitas penginderaan, kapabilitas belajar, kapabilitas integrasi dan kapabilitas koordinasi.

Kapabilitas dinamis yang baik mendukung kualitas operasional implementasi SAP. Penelitian yang mendukung pernyataan ini dilakukan oleh Lin et al. (2016) yang meneliti secara kuantitatif apakah kapabilitas dinamis berpengaruh terhadap adopsi inovasi manajemen. Studi tersebut dilakukan terhadap 264 perusahaan di Cina melalui pengisian kuesioner penelitian. Hasil penelitian menyimpulkan bahwa dimensi-dimensi kapabilitas dinamis, berpengaruh secara positif terhadap proses inovasi manajemen. Ridder, Bruns, \& Spier (2005) yang melakukan penelitian secara kualitatif di pemerintah daerah Jerman menyimpulkan bahwa kapabilitas dinamis yang berbeda menimbulkan adanya perbedaan model dan rutinitas akrual yang dijalankan. Prasad \& Green (2015) melalui penelitian kuantitatif berusaha menemukan hubungan antara kapabilitas sistem informasi akuntansi yang dinamis terhadap kinerja proses akuntansi serta terhadap kinerja organisasi secara keseluruhan. Hasil penelitian membuktikan adanya hubungan yang kuat dari kapabilitas dinamis untuk mendukung kinerja proses akuntansi dan kinerja organisasi.

Berdasarkan permasalahan di atas, penelitian ini bertujuan untuk menguji dan membuktikan pengaruh kapabilitas dinamis serta kontribusi masing-masing dimensinya terhadap implementasi SAP di SKPD Kabupaten Kediri dan dampaknya pada kualitas laporan keuangan. Penelitian ini penting agar implementasi SAP akrual dapat terwujud dengan baik dan menghasilkan kualitas laporan keuangan SKPD yang semakin meningkat di masa yang akan datang.

\section{Kapabilitas Dinamis sebagai Konstruk Multi- dimensi}

Strategi untuk meningkatkan keunggulan organisasi dengan menekankan pada pentingnya meningkatkan efisiensi organisasi secara garis besar terbagi atas dua paradigma, yakni 'resource based-view' (RBV) yang dicetuskan oleh Penrose (1959) dan 'dynamic capabilities' yang dipelopori oleh Teece et al. (1997). Kapabilitas dinamis awalnya dikembangkan dari berbagai kelemahan yang ada pada konsep RBV. RBV dengan penekanan pada akumulasi sumberdaya yang bersifat valuable, rare, inimitable dan non-substituable (VRIN) sehingga membuat suatu organisasi memiliki keunggulan dianggap tidak lagi cukup. RBV dianggap terlalu statis, fokus pada akumulasi sumber daya dan mengabaikan lingkungan eksternal yang sangat dinamis (El Gizawi 2014; Teece et al. 1997). Proeller et al. (2014) menganggap bahwa RBV tidak dapat menjelaskan dengan baik bagaimana sekelompok sumber daya yang bersifat VRIN dapat dirubah menjadi suatu keunggulan kompetitif. RBV dianggap hanya bertumpu pada sumber daya yang bersifat fungsional, seperti ketrampilan teknik atau pemasaran dari pegawai, dan mengabaikan sumberdaya infrastruktur, seperti karakter operasional yang cocok bagi organisasi (Medcof 2000).

Kapabilitas dinamis menekankan pada dua aspek kunci, yakni "kapabilitas" dan "dinamis". Kapabilitas mengacu pada pentingnya peran manajemen stratejik untuk beradaptasi, mengintegrasikan dan menyusun ulang ketrampilan, sumber daya, dan kompetensi fungsional organisasi. Dinamis mengacu pada kapasitas untuk memperbarui kompetensinya seiring dengan perubahan lingkungan. Inti dari definisi ini bukanlah pada akumulasi sumberdaya yang strategis, namun lebih kepada bagaimana cara untuk mengintegrasikan dan mengonfigurasikan agar tetap selaras dengan perubahan tuntutan lingkungan atau bahkan menciptakan perubahan lingkungan.

Kapabilitas dinamis dengan demikian merupakan perilaku organisasi yang selalu berupaya untuk mengintegrasikan, membentuk ulang, memperbarui dan menciptakan kembali rutinitas operasionalnya dalam upaya merespon perubahan lingkungan (Helfat et al. 2007; Wang \& Ahmed 2007). Untuk memiliki kemampuan yang luas tersebut, para akademisi menjabarkannya dalam dimensi-dimensi agar dapat diukur dengan lebih baik (Pavlou \& Sawy 2011), Wang \& Ahmed 2007, Den Hertog et al. 2010). Pavlou \& El Sawy (2011) menglasifikasikannya dalam empat dimensi, yakni kepekaan untuk dapat membaca perubahan eksternal yang terjadi (sensing capability), kemampu- 
an belajar agar organisasi dapat secara aktif meningkatkan kreativitasnya (learning capability), menyatukan pengetahuan baru ke dalam rutinitas kolektif organisasi (integrating capability), dan mendistribusikan sumber daya dan aktivitas secara merata untuk merealisasikan pengetahuan baru (coordinating capability). Para pendukung konstruk multidimensi menyatakan bahwa konstruk tersebut mampu merepresentasikan fenomena yang kompleks secara keseluruhan, mampu mengakomodasi harapan peneliti untuk menandingkan prediktor yang luas dengan hasil yang luas, dan meningkatkan penjelasan atas varian yang muncul (Edwards, 2001).

Sensing capability/kapabilitas penginderaan mengacu kepada kemampuan untuk menentukan, menginterpretasikan dan mengejar kesempatan yang ada pada lingkungan eksternalnya (Pavlou \& Sawy 2011). Den Hertog et al. (2010) mendefinisikan kapabilitas penginderaan sebagai kemampuan untuk merasakan dan mengidentifikasi adanya perubahan pasar. Wang \& Ahmed (2007) mendefinisikannya sebagai kemampuan sebuah organisasi untuk mengidentifikasi dan mengkapitalisasi kesempatan yang muncul dari lingkungan eksternal. Berdasarkan definisi tersebut, kapabilitas penginderaan dapat disimpulkan sebagai sensitivitas organisasi untuk mengidentifikasi, menginterpretasikan dan mengkapitalisasi kesempatan yang ada akibat adanya perubahan eksternal.

Learning capability/Kapabilitas belajar menurut Pavlou \& Sawy (2011) adalah kemampuan untuk menemukan solusi, menciptakan pengetahuan baru, dan menyusun ulang kapabilitas operasional dalam mengembangkan inovasi baru. Kapabilitas belajar sangat diperlukan agar organisasi dapat secara aktif meningkatkan kreativitasnya untuk mencapai keunggulan kompetitif terhadap para pesaingnya. Den Hertog et al. (2010) mendefinisikannya sebagai kemampuan organisasi untuk belajar dari pengalaman agar dapat beradaptasi terhadap proses inovasi yang baru didapatkan. Menurut mereka, organisasi harus memiliki kemampuan belajar melalui kegiatan monitoring dan evaluasi dalam setiap aktivitas untuk menghasilkan inovasi berupa jasa/produk yang baru. Kemampuan monitoring dan evaluasi tersebut tentu saja harus selalu diperbarui menyesuaikan dengan perubahan proses dari inovasi itu sendiri yang bersifat dinamis.

Pavlou \& Sawy (2011) menjelaskan bahwa integrating capability/kapabilitas integrasi adalah kemampuan organisasi dalam menyatukan pengetahuan baru ke dalam kapabilitas operasional melalui penciptaan pemahaman bersama dan pemikiran kolektif. Karena pengetahuan baru biasanya dipelajari secara individual, maka kapabilitas ini sangat penting peranannya dalam mengkombinasikan pengetahuan individual tersebut dalam membangun pemahaman bersama, menciptakan dasar-dasar organisasi dan mengembangkan skema persepsi bersama agar organisasi dapat berjalan dengan efektif. Den Hertog et al. (2010) menyebutnya sebagai kemampuan organisasi untuk menyusun ide baru yang muncul menjadi konsep detail yang dapat diterapkan. Penerapan ide baru mengacu kepada usaha untuk mengkombinasikan pengetahuan yang diadopsi dengan sumber daya internal yang telah ada dalam menghasilkan sebuah inovasi.

Coordinating capability/kapabilitas koordinasi adalah kemampuan untuk mengatur dan membagi tugas dengan baik, serta mendistribusikan sumber daya dan aktivitas secara merata. Kapabilitas koordinasi memungkinkan organisasi dalam mengenali, menyusun dan mengalokasikan sumber daya dengan tepat dan melakukan penyelarasan tugas dan aktivitas agar aktivitas inovasi dapat berjalan dengan baik. Wang \& Ahmed (2007), mendefinisikannya sebagai kemampuan organisasi dalam menghasilkan produk, jasa maupun pasar yang baru melalui penyelarasan (koordinasi) orientasi inovasi stratejik dengan perilaku dan proses inovatif.

\section{Implementasi SAP}

Implementasi dalam penelitian ini dipandang sebagai suatu hasil. Pada sektor pemerintahan, hasil implementasi tersebut disebut sebagai "policy outcome" atau "policy impact" yang mendeskripsikan hasil-hasil dari suatu kebijakan. Ukuran implementasi dari sudut pandang ini dinilai dari sejauh mana suatu tujuan yang telah direncanakan telah tercapai seperti yang diinginkan.

Implementasi akuntansi pemerintahan di Indonesia berkembang seiring dengan perubahan sosial dan politik yang mempengaruhi sistem politik dan pemerintahan Indonesia. Halim \& Kusufi $(2013$; 206) membagi tahapan perkembangan akuntansi pemerintahan di Indonesia atas empat periode.

Tahapan implementasi akuntansi pemerintahan tersebut dimulai pada tahun 1974-an, saat belum ada peraturan pemerintah yang secara spesifik mengatur tentang akuntansi pemerintahan, hingga saat ini yang ditandai dengan terbitnya PP Nomor 71 Tahun 2010 tentang Standar Akuntansi Pemerintahan. Penetapan aturan ini menjadi tonggak sejarah diterapkannya basis akuntansi akrual di Indonesia.

SAP berbasis akrual diadopsi oleh pemerintah Indonesia dengan harapan akan dapat mendorong pemerintah dalam memperbaiki kinerja 
keuangannya secara keseluruhan, baik dalam hal penyusunan anggaran maupun realisasi anggaran. Pada era ini, basis akuntansi akrual juga diterapkan pada tingkat pemerintah daerah melalui Permendagri 64 Tahun 2013.

Implementasi basis akuntansi akrual pada pemerintahan daerah di Indonesia mempunyai peluang dan tantangan masing-masing sesuai dengan karakteristik daerah. Setiap daerah memiliki strategi dan metode implementasi masingmasing yang disusun sesuai dengan potensi wilayahnya. Oleh karena itu diperlukan metode implementasi yang paling tepat agar basis akuntansi akrual dapat diterapkan di daerah dengan baik sesuai dengan peraturan yang berlaku.

\section{Kualitas Laporan Keuangan}

Tujuan utama dari pelaporan keuangan adalah untuk menyediakan laporan keuangan berkualitas yang berguna bagi pengambilan keputusan. Chen, Tang, Jiang, \& Lin (2010) mendefinisikan kualitas laporan keuangan sebagai "the extent to which the financial statements provide true and fair information about the underlying performance and financial position". Dari definisi ini, kualitas laporan keuangan diukur dari kebenaran dan kejujurannya dalam mengungkapkan kinerja dan posisi keuangan suatu organisasi.

Pengertian yang lebih luas disampaikan oleh Jonas \& Blanchet yang dikutip oleh Van Beest et al (2009) dimana kualitas laporan keuangan didefinisikan sebagai “...quality financial reporting is full and transparent financial information that is not designed to obfuscate or mislead users". Berdasarkan definisi ini, Van Beest et al. (2009) menyimpulkan bahwa laporan keuangan yang berkualitas dapat dilihat dari dua perspektif. Pertama adalah dari perspektif kebutuhan pengguna, dimana kualitas laporan keuangan diukur dari kebergunaan informasi yang dihasilkan bagi penggunanya. Untuk mencapai tingkat kebergunaan yang tinggi, laporan keuangan harus menyajikan informasi yang relevan bagi pengambilan keputusan penggunanya. Kedua adalah dari perspektif perlindungan stock/shareholder, dimana kualitas laporan keuangan diukur dari keyakinan bahwa informasi yang disajikan telah mencukupi kebutuhan pengguna, transparan dan kompeten.

Wang \& Strong (1996) menyatakan bahwa data yang berkualitas harus memenuhi empat atribut, yakni kualitas intrinsik, kualitas kontekstual, kualitas representasional, dan kualitas aksesibilitas. Kualitas intrisik menyangkut keakuratan, obyektivitas, keterpercayaan, dan reputasi data. Kualitas intrinsik yang paling nyata dalam laporan keuangan dapat dilihat dari hasil audit atas laporan tersebut. Kualitas intrinsik memang sangat menentukan, namun juga harus didukung secara kontekstual dengan relevansinya, ketepatan waktu penyampaiannya, nilai tambah yang dihasilkan, serta kelengkapan datanya. Juga harus didukung dengan kemampuannya untuk dapat dipahami, keringkasan dan konsistensinya serta kemudahan dan kemanan data untuk didapatkan.

Kualitas laporan keuangan menurut Chen et al. (2010), Van Beest et al. (2009), dan Wang \& Strong (1996) pada prinsipnya terwujud dalam karakteristik kualitatif laporan keuangan sebagaimana terdapat dalam PSAK. Karakteristik kualitatif tersebut meliputi relevansi laporan keuangan, keandalan datanya, kemampuannya untuk dapat dipahami, dan kemampuannya untuk dapat dibandingkan. Dengan demikian dapat disimpulkan bahwa kualitas laporan keuangan adalah laporan keuangan yang disajikan secara relevan, andal, dapat dipahami, dan dapat dibandingkan. Relevan terkait dengan maksud penggunaannya, yakni untuk membantu dalam mengevaluasi peristiwa masa lalu atau masa kini, memprediksi masa depan serta menegaskan atau mengoreksi hasil evaluasi di masa lalu. Informasi keuangan yang andal terkait dengan perlindungan stock/ shareholder dengan menyajikan informasi yang tidak menyesatkan, tidak berisi kesalahan material, menyajikan setiap fakta secara jujur, serta dapat diverifikasi. Dapat dipahami berarti berisi penjelasan yang cukup, dengan susunan dan istilah-istilah yang umum digunakan. Terakhir bahwa laporan keuangan harus dapat dibandingkan dengan laporan lain yang setara maupun dengan periode sebelumnya.

\section{Pengembangan Hipotesis}

Tingkat kapabilitas dinamis yang baik menghasilkan kesuksesan atas implementasi suatu inovasi/perubahan (Lin et al., 2016). Dengan kapabilitas dinamis yang baik akan menghasilkan strategi implementasi SAP, rutinitas teknis, dan sistem informasi akuntansi yang berkualitas yang akan bermuara pada implementasi yang baik (Prasad \& Green, 2015; Ridder et al., 2005).

Kapabilitas penginderaan sebagai kemampuan untuk menentukan, menginterpretasikan dan mengejar kesempatan yang ada pada lingkungan eksternalnya akan mendukung organisasi menyiapkan diri secara dini terhadap adanya dorongan perubahan yang disebabkan oleh adanya perubahan SAP. Penginderaan yang baik ditandai dengan kemampuan untuk dapat melakukan pengukuran segala kebutuhan perubahan dan 
mengefektifkan segala penyesuaian yang dibutuhkan (Den Hertog et al., 2010; Pavlou \& El Sawy, 2011).

Perubahan menuntut adanya kemampuan untuk menemukan solusi atas berbagai permasalahan yang muncul, menciptakan pengetahuan baru yang sesuai dengan organisasinya, dan menyusun ulang kapabilitas operasional dalam mengimplementasikan perubahan. Kapabilitas belajar sangat diperlukan agar organisasi dapat secara aktif meningkatkan kreativitas dan ketrampilan dalam menanggapi setiap kesempatan yang muncul (Pavlou \& El Sawy, 2011). Perubahan selalu menuntut pembelajaran, dan sebaliknya pembelajaran menimbulkan adanya perubahan.

Pengetahuan baru yang didapatkan dari adanya perubahan harus dapat diintegrasikan ke dalam rutinitas operasional organisasi. Wang \& Ahmed (2007) menyatakan bahwa integrasi dapat diwujudkan melalui penciptaan pemahaman bersama dan pemikiran kolektif. Sumbangan pengetahuan individual bagi organisasi sangat penting peranannya dalam membangun skema persepsi bersama agar organisasi dapat melakukan implementasi perubahan dengan efektif.

Koordinasi yang baik untuk mendistribusikan sumber daya dan aktivitas secara merata akan memungkinkan organisasi untuk beroperasi dengan tepat dan menyelaraskan tugas dan aktivitas agar implementasi perubahan dapat berjalan dengan baik (Pavlou \& El Sawy, 2011; Teece et al., 1997; Wang \& Ahmed, 2007). Dengan koordinasi yang baik, segala sumber daya akan bergerak secara simultan menuju target yang direncanakan organisasi.

Penelitian empiris Pavlou \& El Sawy (2011) terhadap 180 unit NPD pada 180 perusahaan yang berbeda di Amerika Serikat menyimpulkan bahwa kapabilitas dinamis mempunyai dampak langsung yang signifikan terhadap kapabilitas operasional organisasi. Kapabilitas operasional sebagai kemampuan untuk melakukan kebiasaan-kebiasaan harian/routine yang efektif sebagaimana yang diungkapkan oleh Pavlou \& El Sawy (2011) dapat disejajarkan dengan kemampuan organisasi untuk melakukan implementasi dan operasionalisasi suatu kebijakan. Dalam konteks kebijakan perubahan basis akuntansi, maka kesuksesan implementasi SAP akrual merupakan indikator capaian kinerja organisasi yang diharapkan. Proses perubahan tersebut membutuhkan tingkat adopsi yang baik melalui berbagai perubahan rutinitas organisasi.

Kapabilitas dinamis yang dipahami dan dibangun secara internal dalam organisasi pemerintah daerah dapat dimanfaatkan untuk mencapai tujuan tersebut. Dengan kemampuan untuk membuat pola yang stabil untuk mengubah dan menyusun ulang rutinitas operasionalnya (Zollo \& Winter, 2002), maka proses rutinitas SAP akrual dapat diimplementasikan dengan baik dalam organisasi. Dengan demikian, hipotesis yang dapat diajukan adalah:

$\mathbf{H}_{1}$ : Konstruk kapabilitas dinamis berpengaruh terhadap implementasi SAP.

Peningkatan kinerja merupakan isu yang sangat mengemuka yang harus dihadapi oleh sektor publik. Untuk mencapai kinerja yang lebih baik tersebut, pemerintah membentuk berbagai dasar aturan yang harus diimplementasikan. Dalam konteks reformasi finansial di Indonesia, hal tersebut diwujudkan dengan terbitnya paket perundangan di bidang keuangan negara serta peraturan pelaksanaannya. Diantara aturan tersebut adalah PP 71 Tahun 2010 dan Permendagri 64 Tahun 2013 terkait dengan standar akuntansi pemerintahan berbasis akrual.

Standar akuntansi merupakan pedoman yang mengatur perlakuan akuntansi dalam penyusunan laporan keuangan yang ditujukan kepada para pengguna laporan keuangan (Mardiasmo, 2009; 148). Dengan standar akuntansi, maka semua proses akuntansi akan dijalankan dengan protokol yang konsisten sehingga laporan keuangan pemerintah yang dihasilkan akan berkualitas, reliabel, obyektif, dan dapat dipahami secara universal Mardiasmo (2009; 149).

Berbagai penelitian membuktikan secara jelas bahwa implementasi SAP dapat meningkatkan kualitas laporan keuangan. Penelitian oleh Nugraheni \& Subaweh (2008) yang dilakukan pada Inspektorat Jenderal Departemen Pendidikkan Nasional menyimpulkan adanya hubungan positif antara implementasi SAP dengan kualitas laporan keuangan. Hal senada diungkapkan oleh penelitan yang dilakukan oleh Juwita (2013) dan Munasyir (2015). Meskipun pada penelitian tersebut terdapat faktor lain yang dapat meningkatkan kualitas laporan keuangan, seperti Sistem Informasi Akuntansi dan Sistem Pengendalian Intern, namun implementasi SAP secara parsial menjadi penyebab yang kuat dalam meningkatkan kualitas laporan keuangan. Dengan demikian, hipotesis yang dapat diajukan adalah:

$\mathbf{H}_{2}$ : Implementasi SAP berpengaruh terhadap kualitas laporan

\section{METODE PENELITIAN}

\section{Unit Analisis dan Unit Observasi}

Unit analisis dalam penelitian ini adalah Satuan Kerja Perangkat Daerah (SKPD) sebagai suatu organisasi. Penentuan unit analisis ini didasarkan pada pertimbangan bahwa berbagai indikator penilaian variabel-variabel dalam pene- 
litian ini akan lebih obyektif jika dideteksi dengan pendekatan organisasi. Implementasi SAP dan laporan keuangan sebagai fokus penelitian merupakan produk sebuah organisasi dan bukan merupakan produk individual. Demikian pula, konsep kapabilitas dinamis merupakan konsep organisasi yang merupakan refleksi dari seluruh kompetensi individu dalam mengelola sumberdaya organisasi. Unit observasi dalam penelitian ini adalah informan kunci yang meliputi para pegawai yang terlibat dalam proses akuntansi SKPD.

\section{Populasi dan Sampel Penelitian}

Penelitian ini mengambil obyek tentang implementasi SAP dan kualitas laporan keuangan SKPD yang dilaksanakan oleh pejabat yang berwenang. SKPD yang dimaksud dalam penelitian ini dibatasi pada lingkup SKPD non-kewilayahan. SKPD yang bersifat kewilayahan seperti Kantor Kecamatan dan Kelurahan tidak dipilih dengan pertimbangan bahwa transaksi-transaksi yang terjadi pada SKPD kewilayahan bersifat sederhana, dan khusus pada Pemerintah Kabupaten Kediri tidak terdapat catatan auditor dalam pengelolaan keuangan SKPD kewilayahan. Populasi penelitian ini terdiri atas 64 orang yang terbagi dalam 32 SKPD. Dari total 64 buah kuesioner yang disebarkan, sejumlah 17 buah (26\%) tidak dikembalikan dan terdapat 3 buah (5\%) kuesioner yang tidak dapat diolah karena tidak diisi secara lengkap ataupun karena tidak dijawab secara benar. Profil atas 44 orang yang menjadi unit observasi tampak dalam Tabel 2 .

Tabel 2. Profil Responden

\begin{tabular}{llcr}
\hline \multicolumn{1}{c}{ Kriteria } & \multicolumn{1}{c}{ Kategori } & Jumlah & \multicolumn{1}{c}{$\%$} \\
\hline Jenis Kelamin & Pria & 25 & $57 \%$ \\
& Wanita & 19 & $43 \%$ \\
\hline Umur & $<25$ Tahun & - & $0 \%$ \\
& 25-30 Tahun & 2 & $5 \%$ \\
& 31-35 Tahun & 5 & $11 \%$ \\
& 36-40 Tahun & 8 & $18 \%$ \\
& $>$ 40 Tahun & 29 & $66 \%$ \\
\hline Tingkat & SLTA/Sederajat & 4 & $9 \%$ \\
Pendidikan & Diploma & 3 & $7 \%$ \\
& S1 & 25 & $57 \%$ \\
& S2 & 12 & $27 \%$ \\
\hline Jabatan & PPK & 23 & $52 \%$ \\
& Staf akuntansi & 21 & $48 \%$ \\
\hline Pengalaman & $<2$ Tahun & - & $0 \%$ \\
Kerja PNS & 2-5 Tahun & - & $0 \%$ \\
& 5-8 Tahun & 12 & $27 \%$ \\
& $>8$ Tahun & 32 & $73 \%$ \\
\hline Pengalaman & $<2$ Tahun & 6 & $14 \%$ \\
Kerja Bidang & 2-5 Tahun & 9 & $20 \%$ \\
Akuntansi & 5-8 Tahun & 10 & $23 \%$ \\
& $>8$ Tahun & 19 & $43 \%$ \\
\hline
\end{tabular}

\section{Teknik Analisis Data}

Analisis data dalam penelitian ini dilakukan secara deskriptif maupun inferensial. Statistik deskriptif dalam penelitian ini meliputi penyajian data dalam bentuk tabel, perhitungan rerata, perhitungan prosentase dan perhitungan standar deviasi. Hasil jawaban responden atas item-item pernyataan dalam kuesioner diolah dengan cara dikelompokkan dan ditabulasikan untuk kemudian diberikan deskripsi untuk mendapatkan gambaran yang lebih baik.

Analisis inferensial menggunakan Structural Equation Modelling (SEM) dari perangkat lunak Smart-Partial Least Square (Smart-PLS) 3.0. Analisis yang digunakan adalah analisis multidimensi pada konstruk kapabilitas dinamis yang tersusun atas variabel-variabel kapabilitas penginderaan, kapabilitas belajar, kapabilitas integrasi, dan kapabilitas koordinasi (Pavlou \& El Sawy, 2011). PLS digunakan dalam penelitian ini diantaranya karena kemampuannya untuk mengolah data dalam jumlah yang kecil, melahirkan hasil uji yang kokoh meskipun tidak mensyaratkan data yang berdistribusi normal, serta mampu memodelkan banyak variabel dependen dan independen (Abdillah \& Jogiyanto 2015). Analisis multidimensi dalam penelitian ini menggunakan repeated indicators approach sebagaimana yang disarankan oleh Wold (Lohmoller 1989 dalamChin, Marcolin, \& Newted 2003).

\section{Uji Bias Non-Respon}

Bias nonrespon adalah bias yang disebabkan karena adanya perbedaan yang signifikan antara jawaban atau profil responden yang mengembalikan kuesioner dengan yang tidak mengembalikan kuesioner. Armstrong \& Overton (1977) menggunakan 3 jenis teknik estimasi untuk memperkirakan dampak non-respon terhadap penelitian, dimana salah satunya digunakan dalam penelitian ini yakni dengan membandingkan jawaban responden yang tertarik pada penelitian terhadap responden yang tidak tertarik pada penelitian.

Melalui uji independent-t test dari SPSS 17.0 sebagaimana tampak dalam Tabel 3, menghasilkan nilai signifikansi $P$-Value di atas 0,05 , sehingga dapat disimpulkan bahwa tidak ada perbedaan jawaban antara responden yang mengembalikan kuesioner pada penelitian dengan responden yang tidak mengembalikan kuesioner. 
Tabel 3. Hasil Uji Beda Independent $t$-Test

\begin{tabular}{cclrrrrr}
\hline Konstruk & Dimensi & & F & Sig. & \multicolumn{1}{c}{ T } & Df & Sig. (2 tailed) \\
\hline KD & KP & Equal variances assumed & .805 & .381 & 1.097 & 18 &. $\mathbf{. 2 8 7}$ \\
& KB & Equal variances assumed & .508 & .485 & .372 & 18 & $\mathbf{. 7 1 4}$ \\
& KI & Equal variances assumed & .336 & .569 & .152 & 18 & $\mathbf{. 8 8 1}$ \\
& KK & Equal variances assumed & 6.486 & .020 & -.739 & 18 & $\mathbf{. 3 0 3}$ \\
ISA & & Equal variances assumed & .000 & .983 & -1.060 & 18 & $\mathbf{. 3 0 3}$ \\
KLK & & Equal variances assumed & .430 & .520 & .395 & 18 & $\mathbf{. 6 9 7}$ \\
\hline
\end{tabular}

\section{HASIL PENELITIAN DAN PEMBAHASAN}

\section{Statistika Deskriptif}

Tabel 4 menunjukkan bahwa pada variabel kapabilitas dinamis dan dimensinya menunjukkan angka rata-rata lebih dari 5 dari skala 7 . Hal ini dapat diinterpretasikan bahwa responden menyetujui bahwa SKPD Pemerintah Kabupaten Kediri memiliki kapabilitas dinamis, implementasi SAP, dan kualitas laporan keuangan yang baik.

Tabel 4. Statistik Deskriptif

\begin{tabular}{cccccc}
\hline Konstruk & Dimensi & Min. & Maks. & Rerata & $\begin{array}{c}\text { Std. } \\
\text { Dev. }\end{array}$ \\
\hline & KP & 2 & 7 & 5.33 & 1.24 \\
KD & KB & 2 & 7 & 5.40 & 1.10 \\
& KI & 3 & 7 & 5.66 & 0.95 \\
ISA & KK & 2 & 7 & 5.78 & 1.09 \\
KLK & & 2 & 7 & 5.74 & 1.12 \\
\hline
\end{tabular}

Skor terendah untuk setiap dimensi kapabilitas dinamis adalah pada indikator kemampuan melakukan pengamatan terhadap lingkungan eksternal, efektivitas dalam mengubah informasi menjadi pengetahuan baru, kehati-hatian dalam menghubungkan tindakan anggota dengan tindakan orang lain, dan kemampuan menyesuaikan keahlian anggota dengan proses kerja. Pada variabel implementasi SAP, skor terendah adalah pada indikator kemampuan mengakui akun LO pada saat yang tepat. Sedangkan pada variabel kualitas laporan keuangan, indikator dengan skor terendah adalah pada keyakinan bahwa laporan keuangan bersifat netral.

\section{Statistika Inferensial}

Pada bagian ini akan dilakukan analisis data dengan menggunakan program Smart-PLS 3.0. Hasil analisis sampel dan hasilnya digunakan untuk menggambarkan keseluruhan kapabilitas dinamis SKPD Pemerintah Kabupaten Kediri dalam menerapkan SAP akrual untuk menghasilkan laporan keuangan yang berkualitas.

\section{Pengujian Model Pengukuran}

Outer model dengan indikator reflektif dalam penelitian ini dievaluasi melalui validitas konvergen dan validitas diskriminan dari setiap indikator manifestasi variabel laten serta dengan composite reliability dan cronbach's alpha untuk setiap blok indikatornya. Tabel 5 menunjukkan bahwa nilai loading factor dari sebagian besar indikator telah menunjukkan angka di atas 0,7.

Tabel 5. Skor Standard Loading, AVE, CA, CR Orde Pertama

\begin{tabular}{|c|c|c|c|c|c|c|}
\hline Konstruk & Dimensi & $\begin{array}{c}\text { Indika- } \\
\text { tor }\end{array}$ & $\begin{array}{c}\text { Std } \\
\text { Loading }\end{array}$ & AVE & CA & CR \\
\hline \multirow{17}{*}{$\mathrm{KD}$} & $\mathrm{KP}$ & KP01 & 0.809 & \multirow{3}{*}{0.641} & \multirow{3}{*}{0.811} & \multirow{3}{*}{0.877} \\
\hline & & KP02 & 0.830 & & & \\
\hline & & $\begin{array}{l}\text { KP03 } \\
\text { KP04 }\end{array}$ & $\begin{array}{l}0.850 \\
0.705\end{array}$ & & & \\
\hline & $\mathrm{KB}$ & KB01 & 0.743 & \multirow{5}{*}{0.580} & \multirow{5}{*}{0.818} & \\
\hline & & KB02 & 0.739 & & & \\
\hline & & KB03 & 0.690 & & & 0.873 \\
\hline & & KB04 & 0.872 & & & \\
\hline & & KB05 & 0.753 & & & \\
\hline & KI & KI01 & 0.713 & \multirow{5}{*}{0.629} & \multirow{5}{*}{0.852} & \\
\hline & & $\mathrm{KI} 02$ & 0.847 & & & \\
\hline & & KI03 & 0.823 & & & 0.894 \\
\hline & & KI04 & 0.802 & & & \\
\hline & & KI05 & 0.773 & & & \\
\hline & KK & KK01 & 0.800 & \multirow{4}{*}{0.673} & \multirow{4}{*}{0.837} & \\
\hline & & KK02 & 0.838 & & & \\
\hline & & KK03 & 0.877 & & & 0.891 \\
\hline & & KK04 & 0.761 & & & \\
\hline \multirow{10}{*}{ ISA } & & ISA01 & 0.830 & \multirow{10}{*}{0.595} & \multirow{10}{*}{0.923} & \\
\hline & & ISA02 & 0.864 & & & \\
\hline & & ISA03 & 0.854 & & & \\
\hline & & ISA04 & 0.777 & & & \\
\hline & & ISA05 & 0.740 & & & 0936 \\
\hline & & ISA06 & 0.719 & & & \\
\hline & & ISA07 & 0.663 & & & \\
\hline & & ISA08 & 0.685 & & & \\
\hline & & ISA09 & 0.760 & & & \\
\hline & & ISA10 & 0.796 & & & \\
\hline \multirow{11}{*}{ KLK } & & KLK01 & 0.660 & \multirow{11}{*}{0.635} & \multirow{11}{*}{0.941} & \\
\hline & & KLK02 & 0.861 & & & \\
\hline & & KLK03 & 0.888 & & & \\
\hline & & KLK04 & 0.724 & & & \\
\hline & & KLK05 & 0.859 & & & \\
\hline & & KLK06 & 0.896 & & & 0.950 \\
\hline & & KLK07 & 0.839 & & & \\
\hline & & KLK08 & 0.683 & & & \\
\hline & & KLK09 & 0.837 & & & \\
\hline & & KLK10 & 0.693 & & & \\
\hline & & KLK11 & 0.776 & & & \\
\hline
\end{tabular}


Enam buah indikator memiliki nilai loading factor diantara 0,5 dan 0,7 , namun nilai ini tetap dapat dipertahankan dalam konstruk penelitian. Tabel tersebut juga menunjukkan bahwa nilai AVE untuk setiap variabel laten memiliki nilai di atas 0,5 sehingga telah memenuhi unsur validitas yang baik. Berdasarkan dua kondisi ini, dapat diyakini bahwa model telah memenuhi persyaratan validitas konvergen.

Model penelitian juga telah memenuhi parameter cross loading yang dipersyaratkan. Nilai loading dari hubungan indikator dengan variabel latennya telah menunjukkan nilai yang paling besar dibandingkan dengan nilai loading dari hubungan indikator diluar variabel latennya. Syarat lain untuk dapat memenuhi validitas diskriminan adalah bahwa nilai akar kuadrat AVE harus lebih besar daripada nilai korelasi antar variabel laten. Nilai ini muncul dalam tabel Fornell-Larcker Criterion dalam laporan pengujian algoritma PLS. Tabel 6 menunjukkan bahwa model penelitian ini telah memiliki nilai akar kuadrat AVE yang lebih besar daripada nilai korelasi antar variabel laten. Hal ini ditunjukkan dengan nilai Fornell-Larcker Criterion pada nilai diagonal yang lebih besar daripada nilai lain pada kolom dan baris yang sama. Dengan kondisi di atas, dapat disimpulkan bahwa model telah memenuhi persyaratan validitas diskriminan.

Uji reliabilitas model dilakukan dengan melihat hasil nilai composite reliability dan cronbach's alpha hasil pengujian algoritma PLS. Nilai composite reliability dan cronbach's alpha yang dipersyaratkan harus lebih dari 0,7. Hasil uji sebagaimana tampak dalam Tabel 5 menunjukkan bahwa hasil perhitungan algoritma PLS telah memenuhi syarat reliabilitas yang baik dengan nilai lebih dari 0,8 .

Tabel 6. Fornell Larcker Criterion

\begin{tabular}{ccccccc}
\hline & KP & KB & KI & KK & ISA & KLK \\
\hline KP & $\mathbf{0 . 8 0 1}$ & & & & & \\
KB & 0.740 & $\mathbf{0 . 7 6 2}$ & & & & \\
KI & 0.645 & 0.734 & $\mathbf{0 . 7 9 3}$ & & & \\
KK & 0.773 & 0.740 & 0.772 & $\mathbf{0 . 8 2 0}$ & & \\
ISA & 0.658 & 0.668 & 0.718 & 0.737 & $\mathbf{0 . 7 7 2}$ & \\
KLK & 0.639 & 0.652 & 0.786 & 0.776 & 0.770 & $\mathbf{0 . 7 9 7}$ \\
\hline
\end{tabular}

\section{Pengujian Model Struktural}

Chin et al. 2003 menyatakan bahwa nilai $\mathrm{R}^{2}$ sebesar 0,67;0,33 dan 0,19 secara berurutan merepresentasikan model yang kuat, moderat dan lemah. Hasil pengujian sebagaimana tampak dalam Gambar 1 menunjukkan bahwa nilai $\mathrm{R}^{2}$ dari variabel implementasi SAP adalah sebesar 0,612 . Ini menunjukkan bahwa variabel kapabi- litas dinamis dapat menjelaskan varian perubahan variabel implementasi SAP secara moderat sebesar $61,2 \%$, sementara sisanya sebesar $38,8 \%$ dipengaruhi variabel lain diluar penelitian. Nilai $\mathrm{R}^{2}$ dari variabel kualitas laporan keuangan adalah sebesar 0,592. Ini menunjukkan bahwa variabel implementasi SAP dapat menjelaskan varian perubahan variabel kualitas laporan keuangan secara moderat sebesar 59,2\%, sementara sisanya sebesar 40,8\% dipengaruhi variabel lain diluar penelitian.

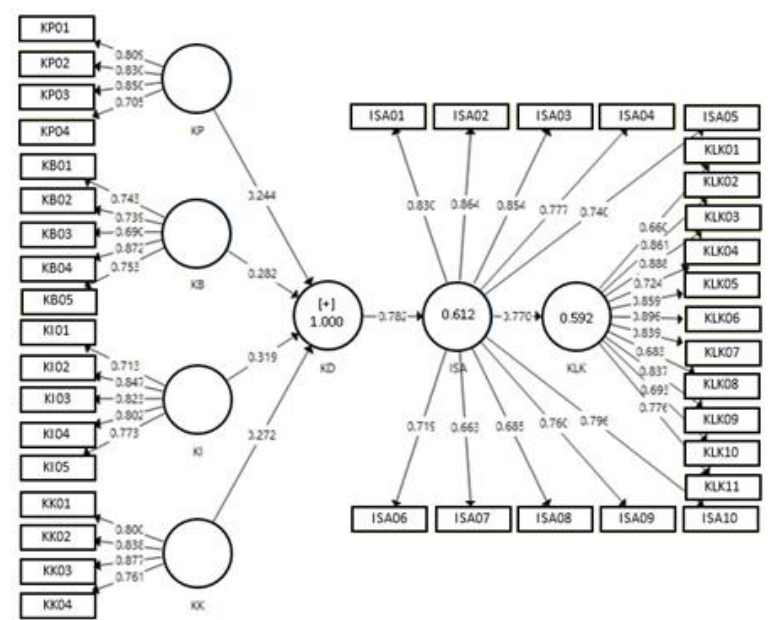

Gambar 1. Hasil Algoritma Smart-PLS

Pengujian model struktural selanjutnya dilakukan dengan melihat nilai $\mathrm{Q}^{2}$. Hasil perhitungan dengan nilai $\mathrm{Q}^{2}$ menghasilkan angka sebesar 0,8416 yang menunjukkan bahwa model penelitian ini memiliki predictive relevance yang baik.

\section{Pengujian Hipotesis}

Hasil pengujian sebagaimana tampak dalam Tabel 7 menunjukkan bahwa Hipotesis $1\left(\mathrm{H}_{1}\right)$ yang menyatakan bahwa konstruk kapabilitas dinamis berpengaruh posistif terhadap implementasi SAP terkonfirmasi ( $t$-statistic $=9,609$ dan $P$-value $<0,05)$. Hasil pengujian juga menerima Hipotesis $2\left(\mathrm{H}_{2}\right)$ yang menyatakan bahwa implementasi SAP berpengaruh positif terhadap kualitas laporan keuangan $(t$-statistic $=9.028$ dan $P$-value $<0,05)$.

\section{Konstruk Kapabilitas Dinamis Berpengaruh terhadap Implementasi SAP}

Hasil pengujian dalam penelitian ini membuktikan bahwa kapabilitas dinamis berpengaruh secara signifikan terhadap implementasi SAP akrual yang harus diterapkan pada tahun 2015 oleh seluruh SKPD Pemerintah Kabupaten Kediri. 
Tabel 7. Uji Hipotesis

\begin{tabular}{ccccccc}
\hline Relasi & Original Sample & Sample Mean & Std. Dev. & T-Statistic & P Value & Kesimpulan \\
\hline KD -> ISA & 0.783 & 0.774 & 0.081 & 9.609 & 0.000 & Diterima \\
ISA -> KLK & 0.770 & 0.770 & 0.085 & 9.028 & 0.000 & Diterima \\
\hline
\end{tabular}

Bukti empiris ini mendukung hipotesis $1\left(\mathrm{H}_{1}\right)$ yang menyatakan bahwa terdapat hubungan positif kapabilitas dinamis terhadap implementasi SAP. Semakin baik kapabilitas dinamis, semakin baik pula implementasi SAP.

Hasil penelitian ini sejalan dengan penelitian sebelumnya yang dilakukan oleh Pavlou \& Sawy (2011), Ridder, Bruns, \& Spier (2005), dan Prasad \& Green (2015). Pavlou \& El Sawy (2011) yang menyatakan bahwa kapabilitas dinamis berpengaruh secara signifikan terhadap kapabilitas operasional suatu organisasi. Kapabilitas operasional adalah proses rutinitas organisasi dalam melaksanakan kegiatannya sehari-hari, dimana ini identik dengan proses implementasi aktivitas organisasi. Prasad \& Green (2015) secara khusus menyimpulkan pengaruh kapabilitas dinamis sistem informasi organisasi yang berdampak positif terhadap proses kinerja akuntansi yang pada akhirnya akan meningkatkan kinerja organisasi secara keseluruhan. Adaptasi standar akuntansi baru yang dilakukan secara idiosinkratik menyebabkan adanya keragaman dalam proses implementasinya (Ridder, Bruns, \& Spier 2005).

Berdasarkan penjelasan di atas, kapabilitas dinamis terbukti merupakan suatu kemampuan yang sangat penting bagi SKPD dalam upaya mendapatkan kualitas implementasi SAP yang tinggi. Kemampuan tersebut meliputi kapabilitas untuk melakukan penginderaan terhadap perubahan regulasi lingkungan akan mendukung proses pembelajaran organisasi (Day 1994; Sinkula, Baker, \& Noordewier 1997). Kemampuan belajar tersebut diperlukan agar organisasi dapat secara aktif memahami informasi perubahan dan mengubahnya menjadi pengetahuan bagi organisasi (Liu, Luo, \& Shi 2002). Pengetahuan tersebut akan melahirkan visi bersama yang memungkinkan setiap anggota organisasi berkontribusi mengintegrasikannya dalam organisasi (Pavlou \& El Sawy 2011; Kogut \& Zander 1992), dan melakukan koordinasi untuk memastikan terjadinya proses implementasi pengetahuan yang terdistribusi dalam setiap fungsi organisasi secara adil, selaras antar bagian dalam organisasi, serta menjamin kecukupan sumber daya implementasi (Malone \& Crowston, 1990; Ridder, Bruns, \& Spier 2005).

Hasil statistik deskriptif dimensi-dimensi kapabilitas dinamis menunjukkan bahwa secara umum responden setuju bahwa SKPD Pemerintah
Kabupaten Kediri memiliki kapabilitas dinamis yang baik. Namun demikian, fenomena yang muncul di tahun 2015 melalui kurang optimalnya opini atas laporan keuangan yang dihasilkan menunjukkan bahwa implementasi SAP masih belum dapat berjalan dengan baik. Oleh karena itu, kapabilitas dinamis pada tingkat SKPD Pemerintah Kabupaten Kediri sangat perlu untuk ditingkatkan agar implementasi SAP dapat berjalan dengan lebih baik dan konsisten. Lin et al. (2016) menyatakan bahwa siklus dan tahapan implementasi SAP harus diperhatikan agar dapat diperoleh komposisi dimensi kapabilitas dinamis mana saja yang harus lebih ditekankan.

\section{Kontribusi Dimensi terhadap Konstruk Laten}

Kapabilitas dinamis merupakan sebuah konstruk multidimensi. Pada bagian ini akan dijabarkan bagaimana dimensi kapabilitas penginderaan, kapabilitas belajar, kapabilitas integrasi dan kapabilitas koordinasi memberikan kontribusinya terhadap konstruk kapabilitas dinamis. Tabel 8 menunjukkan peringkat kontribusi setiap dimensi dalam penelitian ini berdasarkan nilai $t$ statistic yang dihasilkan.

Tabel 8. Kontribusi Dimensi

\begin{tabular}{|c|c|c|c|c|c|c|}
\hline Relasi & $\begin{array}{l}\text { Original } \\
\text { Sample }\end{array}$ & $\begin{array}{c}\text { Sample } \\
\text { Mean }\end{array}$ & $\begin{array}{l}\text { Std. } \\
\text { Dev. }\end{array}$ & $\begin{array}{c}\mathrm{T}- \\
\text { Statistic }\end{array}$ & $\begin{array}{c}\mathrm{P} \\
\text { Value }\end{array}$ & $\begin{array}{c}\text { Rank- } \\
\text { ing }\end{array}$ \\
\hline$\overline{\mathrm{KP}}->\mathrm{KD}$ & 0.242 & 0.243 & 0.024 & 10.160 & 0.000 & III \\
\hline $\mathrm{KB}->\mathrm{KD}$ & 0.280 & 0.290 & 0.041 & 6.843 & 0.000 & IV \\
\hline $\mathrm{KI} \quad>\mathrm{KD}$ & 0.317 & 0.321 & 0.030 & 10.401 & 0.000 & II \\
\hline $\mathrm{KK}->\mathrm{KD}$ & 0.277 & 0.275 & 0.025 & 10.936 & 0.000 & I \\
\hline
\end{tabular}

\section{Kontribusi Kapabilitas Penginderaan}

Kapabilitas pengideraan dalam penelitian ini, sebagaimana tampak pada Tabel 8, memberikan kontribusi pada urutan ke-3 dari empat dimensi kapabilitas dinamis. Day (1994), menyatakan bahwa organisasi yang memiliki kemampuan penginderaan yang baik akan mendapatkan keunggulan kompetitif dan kinerja organisasi yang lebih baik. Dengan penginderaan yang baik akan kondisi lingkungannya, organisasi tidak akan terjebak pada mental myopic dan akan mendapatkan sirkulasi informasi yang baik. Dengan kapabilitas penginderaan yang baik, organisasi akan terhubung dan memiliki keterkaitan dengan stakeholder dan lingkungannya sehingga akan lebih 
responsif dan mampu mengantisipasi perubahan di masa mendatang.

De Groot (2011) mengungkapkan bahwa kegiatan untuk melakukan penginderaan lingkungan dapat dilakukan melalui dua tahapan, yakni pengumpulan informasi dan interpretasi informasi. Pada sektor publik dengan stakeholder yang luas, penginderaan harus dilakukan secara komprehensif. Penginderaan tidak hanya terpusat pada kebutuhan pelanggan dan perubahan teknologi, namun juga harus mempertimbangkan perubahan legislasi, politik, dan struktur masyarakat. Setelah semua kondisi perubahan dapat diidentifikasi, dilakukan interpretasi informasi agar dapat diambil jalur/path organisasi yang hendak ditempuh selanjutnya.

Pada konteks perubahan SAP akrual pada SKPD Pemerintah Kabupaten Kediri, pengumpulan informasi lebih dipicu karena adanya perubahan sosial politik yang menuntut transparansi dan akuntabilitas serta karena adanya perubahan aturan Pemerintah Pusat tentang SAP. Kondisi ini identik dengan kondisi awal sebagian besar negara lain yang mengimplementasikan SAP akrual (Adhikari, Kuruppu, \& Matilal 2013; BuneaBontas \& Petre 2009; Ridder et al. 2005; Tickell 2010). Stigma pemerintahan pusat dan daerah yang tidak produktif, tidak efisien, kurang inovatif, minus kreativitas dengan pelayanan yang lamban dan berbelit harus dihilangkan. Salah satu caranya adalah melalui transparansi dan akuntabilitas pengelolaan keuangan negara yang diadministrasi dengan basis akuntansi akrual. Kondisi sosialpolitik yang berkembang dengan pesat dan tuntutan untuk lebih ekonomis dalam persaingan global ditangkap dengan baik melalui implementasi standar akuntansi pemerintahan berbasis akrual.

\section{Kontribusi Kapabilitas Belajar}

Kapabilitas belajar sebuah organisasi sangat tergantung dari kemampuan belajar para anggotanya yang diterapkan secara deliberatif dengan kesadaran dan keaktifan, bukan bersifat pasif hanya dengan 'learning by doing' (Cohen \& Levinthal, 1990; Zollo \& Winter, 2002). Organisasi yang memiliki nilai-nilai pembelajaran yang baik akan selalu fokus pada perbaikan berkelanjutan yang mengarah pada keterbukaan, inovasi, dan perubahan. Zollo \& Winter (2002) menyatakan bahwa kapabilitas belajar yang melekat dalam organisasi akan meningkatkan nilai rutinitas organisasi menjadi semakin sulit untuk ditiru (inimitable), dan semakin susah digantikan (nonsubstitutable). Hal ini disebabkan karena organisasi akan lebih mampu untuk melakukan evaluasi terhadap konsep-konsep manajemen dan lebih terampil dalam berinovasi yang disesuaikan dengan jalur/path organisasi.

Dalam penelitian ini, sebagaimana tampak pada Tabel 8, kapabilitas belajar memberikan kontribusi paling minim dari empat dimensi kapabilitas dinamis. Kecilnya kontribusi tersebut menunjukkan bahwa kapabilitas paling kurang relevan bagi SKPD Pemerintah Kabupaten Kediri dibandingkan dengan kapabilitas yang lain. Hal tersebut diduga disebabkan oleh dua hal. Pertama, karena terbitnya PP No. 71 Tahun 2010 dan Permendagri No. 64 Tahun 2013 telah diumumkan secara terbuka melalui lembaran negara tahun 2010 Nomor 123 dan lembaran negara tahun 2013 Nomor 1425. Dengan telah diumumkan melalui lembaran negara yang diikuti dengan berbagai bentuk sosialisasi oleh pemerintah pusat, interpretasi atas aturan tersebut juga bersifat sangat terbatas dengan interpretasi legal formal. Dengan demikian kapabilitas belajar menjadi paling kurang relevan bagi SKPD Pemerintah Daerah Kabupaten Kediri. Kedua, pendekatan kebijakan publik yang digunakan pemerintah pusat dalam mengimplementasikan SAP akrual adalah pendekatan kelembagaan menjadikan implementasinya bersifat koersif. Dengan pendekatan kelembagaan, dimana suatu aturan wajib dilaksanakan oleh struktur-struktur pemerintah yang tertuang dalam aturan tersebut (Nugroho 2009), menyebabkan aturan implementasi SAP akrual menjadi bersifat wajib dan memaksa bagi pemerintahan pada tingkatan yang lebih rendah sehingga memunculkan partisipasi yang bersifat pasif dan ceremonial display belaka (Djamhuri 2009; Irvine 2011).

\section{Kontribusi Kapabilitas Integrasi}

Kapabilitas integrasi dalam penelitian ini memberikan kontribusi pada urutan ke-2 (Tabel 8). Kapabilitas integrasi bermanfaat dalam menyatukan pengetahuan baru ke dalam operasional organisasi. Kogut \& Zander (1992) menyatakan bahwa organisasi akan mendapatkan kinerja yang baik apabila terjadi adanya saling berbagi dan transfer pengetahuan antar individu dalam organisasi. Ketrampilan untuk melakukan komunikasi, baik secara internal organisasi maupun dengan pihak di luar organisasi memiliki peran yang sangat penting dalam mendongkrak kapabilitas integrasi (Eisenhardt \& Martin 2000). Melalui komunikasi yang baik akan diperoleh pemahaman bersama dan pemikiran kolektif para anggota organisasi (Pavlou \& El Sawy 2011). Dengan pemahaman yang sama antar personil tentang suatu pengetahuan baru dan keinginan bersama 
untuk dapat mengadopsi pengetahuan tersebut dalam kegiatan organisasi, maka akan muncul kontribusi-kontribusi aktif dari individu-individu organisasi untuk saling mengisi dalam membangun iklim implementasi yang kuat.

Untuk mendapatkan kapabilitas integrasi yang baik, organisasi harus membangun struktur integrasi yang kuat agar dapat mendistribusikan sumberdaya pengetahuan dan relasional organisasi (Gardner et al. 2011). Pengetahuan, pengalaman, dan kemampuan relasi antar individu anggota organisasi terhadap basis akuntansi akrual sebagai tacit knowledge harus dapat diubah menjadi explisit knowledge melalui komunikasi visi dan strategi implementasi, komitmen para pemimpin, dan struktur organisasi. Hasil statistik deskriptif dalam penelitian ini menunjukkan bahwa para anggota SKPD Pemerintah Kabupaten Kediri memiliki kesediaan yang besar untuk memberikan kontribusinya dalam organisasi dan memiliki pemahaman yang kuat tentang kapabilitas masing-masing anggotanya. Melalui kemampuan ini, basis akuntansi akrual sebagai pengetahuan baru dapat diintegrasikan secara kolektif antar anggota organisasi.

\section{Kontribusi Kapabilitas Koordinasi}

Hasil penelitian ini menunjukkan bahwa kapabilitas koordinasi memberikan kontribusi yang paling signifikan terhadap kapabilitas dinamis (Tabel 8). Kapabilitas koordinasi berperan dalam mengatur dan membagi tugas serta mendistribusikan pekerjaan dan sumber daya secara merata (Pavlou \& El Sawy 2011). Distribusi yang merata tidak berarti bahwa seluruh personil/ lembaga mendapatkan porsi kerja yang sama, namun mendapatkan pekerjaan yang sesuai dan setara dengan pengetahuan dan keahlian masingmasing, serta mendapatkan sumber daya yang seimbang dengan derajat kebutuhannya. Koordinasi yang baik akan menyelaraskan antara tujuan yang hendak dicapai dengan aktivitas yang dikerjakan oleh setiap personil/lembaga dan seluruh proses saling ketergantungan antar komponen di dalamnya (Malone \& Crowston, 1990).

Penelitian Ridder, Bruns, \& Spier (2005) menunjukkan bagaimana besar dampak koordinasi yang baik antara tim implementasi dengan key user, pihak eksekutif, dan manajemen puncak yang menjadi pendorong suksesnya implementasi basis akrual. Penelitian tersebut menekankan pada koordinasi yang lebih baik utamanya terhadap pihak eksekutif yang tidak memiliki motivasi intrinsik dalam mengimplementasikan basis akrual sehingga meminimalkan potensi hambatan dalam implementasi basis akrual. Koordinasi yang baik pada tingkat Pemerintah Daerah antara SKPD dengan SKPKD dan BPKP akan berdampak positif dalam menghasilkan pola kerja yang selaras antar personil/lembaga. Pola kerja yang harmonis akan mendukung organisasi dalam mempersiapkan sumber daya manusia yang kompeten serta sarana dan prasarana yang memadai. Koordinasi yang baik akan memastikan setiap personil/lembaga mendapatkan kebutuhan sumber daya yang cukup untuk dapat mengimplementasikan SAP Akrual.

Kapabilitas koordinasi yang baik dapat dicapai melalui kemampuan organisasi dalam mengenali potensi setiap personil dan setiap karakter jenis pekerjaan dengan baik. Dengan pengenalan tersebut, akan diperoleh metode pelatihan maupun workshop yang paling tepat bagi pegawai serta uji coba implementasi yang cukup agar kualitas dan kapabilitas setiap aktor kunci implementasi SAP akrual dapat ditingkatkan. Keberhasilan koordinasi juga akan memastikan kecepatan adaptasi dalam penggunaan siatem informasi yang baru. Sistem informasi yang komprehensif sebagai sarana implementasi SAP Akrual sangat dibutuhkan mengingat berbagai kerumitan yang dihasilkan oleh basis akuntansi akrual sebagaimana dinyatakan oleh Arif, Putra, \& Kurrohman (2013); Damayanti (2013); Sampel, Kalangi, \& Runtu (2015); Widyastuti, Sujana, \& Adiputra (2015) dapat diminimalisir.

\section{Implementasi SAP Berpengaruh terhadap Kualitas Laporan Keuangan}

SAP merupakan pedoman yang mengatur perlakuan akuntansi pemerintahan dalam penyusunan laporan keuangan agar laporan yang dihasilkan dapat dipahami dan dimanfaatkan oleh para pengguna laporan keuangan. PP Nomor 71 Tahun 2010 menyatakan bahwa salah satu manfaat dari disusunnya SAP adalah untuk meningkatkan kualitas laporan kauangan yang dihasilkan oleh organisasi pemerintahan. Laporan keuangan yang disusun berdasarkan SAP akan bersifat umum, netral, dan tidak memihak sehingga dapat dimanfaatkan oleh semua pihak yang berkepentingan sebagai dasar pengambilan keputusan.

Hasil pengujian dalam penelitian ini memberikan dukungan empiris bahwa terdapat hubungan positif implementasi SAP terhadap kualitas laporan keuangan di SKPD Pemerintah Kabupaten Kediri sebagaimana yang dinyatakan dalam Hipotesis $2\left(\mathrm{H}_{2}\right)$. Semakin baik implementasi SAP akrual SKPD Pemerintah Kabupaten Kediri, semakin baik pula kualitas laporan keuangan yang dihasilkan. Hasil penelitian ini men- 
dukung kesimpulan hasil penelitian sebelumnya yang dilakukan oleh Juwita (2013); Munasyir (2015); dan Nugraheni \& Subaweh (2008).

Analisis statistik deskriptif pada konstruk implementasi SAP akrual dalam sub-bab sebelumnya menunjukkan bahwa tiga besar kemampuan SKPD Pemerintah Kabupaten Kediri yang dianggap paling lemah adalah kemampuan dalam menyusun Laporan Operasional yang disusul kemudian dengan kemampuan menilai persediaan dengan tepat dan kemampuan menyajikan aset dengan tepat. Laporan Operasional dan penyajian akun posisi keuangan merupakan intisari dari sistem akrual, sehingga dengan kemampuan yang rendah dalam bidang ini dapat diinterpretasikan bahwa implementasi SAP akrual masih belum dapat dipahami dan dilaksanakan dengan baik oleh SKPD Pemerintah Kabupaten Kediri. Pemahaman dan kemampuan implementasi SAP akrual tersebut, utamanya pada indikator-indikator yang dinilai lemah tersebut, harus dapat ditingkatkan agar laporan keuangan SKPD Pemerintah Kabupaten Kediri dapat lebih berkualitas. Dengan peningkatan kemampuan implementasi SAP akrual, maka permasalahan yang menyebabkan pengecualian atas opini wajar atas Laporan Keuangan Pemerintah Kabupaten Kediri dapat diatasi, dan opini wajar dengan pengecualian atas Laporan Keuangan dapat ditingkatkan menjadi wajar tanpa pengecualian.

\section{KESIMPULAN}

Penelitian membuktikan bahwa kapabilitas dinamis berpengaruh positif terhadap implementasi SAP pada SKPD Pemerintah Kabupaten Kediri. Kurang optimalnya opini atas laporan keuangan yang dihasilkan menunjukkan bahwa implementasi SAP masih belum dapat berjalan dengan baik, sehingga kapabilitas dinamis masih perlu untuk ditingkatkan. Dalam pengembangan kapabilitas dinamis, perlu dipertimbangkan siklus dan tahapan implementasi SAP agar pengembangan masing-masing dimensi kapabilitas dinamis menjadi lebih optimal.

Penelitian ini juga membuktikan bahwa implementasi SAP berpengaruh positif terhadap kualitas laporan keuangan SKPD. Implementasi SAP yang baik berpengaruh dalam kemampuan SKPD untuk menyusun komponen-komponen laporan keuangan secara lengkap, menjalankan prinsip-prinsip pengakuan, penilaian dan penyajian laporan keuangan dengan baik sehingga laporan keuangan yang dihasilkan akan berkualitas.

Hasil penelitian ini memberikan implikasi praktis bagi SKPD Pemerintah Kabupaten Kediri, bahwa untuk meningkatkan kualitas laporan keuangan SKPD diperlukan implementasi SAP yang baik dan konsisten. Implementasi SAP yang baik dan konsisten dapat dibentuk melalui penguasaan yang baik atas dimensi-dimensi kapabilitas dinamis, yakni kapabilitas belajar, kapabilitas integrasi, dan kapabilitas koordinasi. Dengan membangun kapabilitas tersebut, proses penyusunan laporan keuangan akan sesuai dengan PP Nomor 71 Tahun 2010 dan menghasilkan laporan keuangan yang relevan, andal, dapat dibandingkan, dan dapat dipahami. Dengan laporan keuangan yang berkualitas, akan dapat dihindarkan adanya potensi kerugian keuangan daerah yang signifikan.

\section{DAFTAR PUSTAKA}

Abdillah, W. \& Jogiyanto. (2015). Partial Least Square, Alternatif Structural Equation Modelling (SEM) dalam Penelitian Bisnis. Yogyakarta: Andi Offset.

Adhikari, P., Kuruppu, C., \& Matilal, S. (2013). Dissemination and Institutionalization of Public Sector Accounting Reforms in Less Developed Countries: A Comparative Study of the Nepalise and Sri Lankan Central Governments. Accounting Forum, 37, 1-18.

Akuntan Indonesia. (2015, September). Akuntan Indonesia. Akuntan Penyebab Krisis?, pp. 6-9. Jakarta.

Arif, M. M., Putra, H. S., \& Kurrohman, T. (2013). Analisis Kesiapan Pemerintah Daerah Dalam Penerapan Standar Akuntansi Pemerintahan Berbasis Akrual (Studi pada Pemerintah Daerah Kabupaten Bondowoso). Jurnal Akuntansi Universitas Jember, 92-104.

Armstrong, J. S., \& Overton, T. S. (1977). Estimating Nonresponse Bias in Mail Surveys. Journal of Marketing, 14(3), 396-402.

Bunea-Bontas, C. A., \& Petre, M. C. (2009). Arguments for Introducing Accrual Based Accounting in the Public Sector. Munich Personal RePEc Archive, 18134, 43-45.

Chen, H., Tang, Q., Jiang, Y., \& Lin, Z. (2010). The Role of International Financial Reporting Standards in Accounting Quality: Evidence from the European Union. Journal of International Financial Management and Accounting, 21(3), 220-278.

Chin, W. W., Marcolin, B. L., \& Newted, P. R. (2003). A Partial least Squares Latent Variable Modeling Approach For Measuring Interaction Effects: Results From a Monte Carlo Simulation Study and Voice Mail Emotion/ Adoption Study. In Seventeenth International Conference on Information Systems (pp. 2141). 
Cohen, W. M., \& Levinthal, D. A. (1990). Absorptive Capacity: A New Perspective on Learning and Innovation. Administrative Science Quarterly, 35(1), 128-152.

Damayanti, R. A. (2013). Akuntansi Akrual Dan Penerapannya Di Sektor Publik: Sebuah Agenda Pembaruan. In Modul: Akuntansi Pemerintah Berbasis Akrual, Konsep, Pemikiran dan Implementasi di Indonesia (pp. 117). BPKP.

Day, G. S. (1994). The of Market-Drive Capabilities Organizations. Journal of Marketing, 58(4), 37-52.

De Groot, D. (2011). Sensing and Seizing Opportunities in The Public Sector. Universiteit van Amsterdam.

Den Hertog, P., Van der Aa, W., \& De Jong, M. (2010). Capabilities for Managing Service Innovation: Towards a Conceptual Framework. Journal of Service Management, 21(4), 490-514.

Djamhuri, A. (2009). A Case Study of Governmental Accounting and Budgeting Reform at Local Authority in Indonesia: an Institutionalist Perspective. Universiti Sains Malaysia.

Edwards, J. R. (2001). Multidimensional Constructs in Organizational Behavior Research: An Integrative Analytical Framework. Organizational Research Methods, 4(2), 144-192.

Eisenhardt, K. M., \& Martin, J. A. (2000). Dynamic Capabilities: What Are They? Strategic Management Journal, 21, 1105-1121.

El Gizawi, N. (2014). The Dynamic Capabilities Theory: Assessment and Evaluation as a Contributing Theory for Supply Chain Management. In 3rd IBA Bachelor Thesis Conference. Enschede, Netherlands: University of Twente, Faculty of Management and Governance.

Halim, A., \& Kusufi, M. S. (2013). Akuntansi Sektor Publik: dari Anggaran hingga Laporan Keuangan, dari Pemerintah hingga Tempat Ibadah. Jakarta: Salemba Empat.

Helfat, C. E., Finkelstein, S., Mitchell, W., Peteraf, M. A., Singh, H., Teece, D. J., \& Winter, S. G. (2007). Dynamic Capabilities: Understanding Strategic Change in Organizations. USA: Blackwell Publishing.

Irvine, H. (2011). From Go to Woe: How a Not-forProfit Managed the Change to Accrual Accounting. Accounting, Auditing and Accountability Journal, 24(7), 824-847.

Juwita, R. (2013). Pengaruh Implementasi Standar Akuntansi Pemerintahan dan Sistem Informasi Akuntansi Terhadap Kualitas Laporan Keuangan. Trikonomika, 12(2), 201214.
Kogut, B., \& Zander, U. (1992). Knowledge of the Firm, Combinative Capabilities, and the Replication of Technology. Organization Science, 3(3), 383-397.

KSAP. (2010). Prinsip dan Standar Akuntansi Pemerintahan. Jakarta: IAI.

Lin, H. F., Su, J. Q., \& Higgins, A. (2016). How Dynamic Capabilities Affect Adoption of Management Innovations. Journal of Business Research, 69(2), 862-876.

Liu, S. S., Luo, X., \& Shi, Y.-Z. (2002). Integrating customer orientation, corporate entrepeneurship, and learning orientation in organizations-in-transition: an empirical study. International Journal of Research in Marketing, 19(4), 367-382.

Malone, T. W., \& Crowston, K. (1990). What is coordination theory and how can it help design cooperative work systems? In Proceedings of the 1990 ACM conference on Computer-supported cooperative work - CSCW'90 (pp. 357-370).

Mardiasmo. (2009). Akuntansi Sektor Publik (Edisi ke-4). Yogyakarta: Penerbit Andi.

Medcof, J. W. (2000). Dynamic Capabilities: a NeoContingency Theory? (No. 96). Hamilton, Canada.

Munasyir. (2015). Pengaruh Penerapan Standar Akuntansi Pemerintahan dan Sistem Pengendalian Intern Pemerintah Terhadap Kualitas Laporan Keuangan Satuan Kerja Pemerintah Daerah di Kabupaten Aceh Utara. Jurnal Magister Akuntansi Pascasarjana Universitas Syiah Kuala, 4(4), 23-35.

Nugraheni, P., \& Subaweh, I. (2008). Pengaruh Penerapan Standar Akuntansi Pemerintahan Terhadap Kualitas Laporan Keuangan. Jurnal Ekonomi Dan Bisnis, 13(1), 48-58.

Nugroho, R. (2009). Public Policy. Jakarta: PT. Elex Media Komputindo.

Pablo, A. L., Reay, T., Dewald, J. R., A.L., \& Casebeer. (2007). Tdentifying, Enabling and Managing Dynamic Capabilities in the Public Sector. Journal of Management Studies, 44(5), 687-708.

Pavlou, P. A., \& El Sawy, O. A. (2011). Understanding the "Black Box" of Dynamic Capabilities. Management Science, 92521(1), 239273.

Penrose, E. (1959). The Theory of the Growth of the Firm. New York: Oxford University Press.

Prasad, A., \& Green, P. (2015). Organizational Competencies and Dynamic Accounting Information System Capability: Impact on AIS Processes and Firm Performance. Journal of Information Systems, 29(3), 123-149. 
Proeller, I., Kroll, A., Krause, T., \& Vogel, D. (2014). How Dynamic Capabilities Mediate the Link between Strategy and Performance. In P. Joyce \& A. Drumaux (Eds.), Strategic Management in Public Organizations. Taylor \& Francis Group.

Ridder, H.-G., Bruns, H.-J., \& Spier, F. (2005). Analysis of Public Management Change Processes: The Case of Local Government Accounting Reforms in Germany. Public Administration, 83(2), 443-471.

Sampel, I. F., Kalangi, L., \& Runtu, T. (2015). Analisis Kesiapan Pemerintah Kota Manado dalam Penerapan Peraturan Pemerintah Nomor 71 Tahun 2010 Mengenai Standar Akuntansi Basis Akrual. Jurnal EMBA, 3(1), 621-630.

Sinkula, J., Baker, W., \& Noordewier, T. (1997). A framework for market-based organizational learning: Linking values, knowledge, and behavior. Journal of the Academy of Marketing Science, 25, 305-318.

Teece, D., Pisano, G., \& Shuen, A. (1997). Dynamic Capabilities and Strategic Management. Strategic Management Journal, 18(7), 509-533.
Tickell, G. (2010). Cash To Accrual Accounting: One Nation's Dilemma. The International Business \& Economics Research Journal, 9(11), 71-78.

Van Beest, F., Braam, G., \& Boelens, S. (2009). Quality of Financial Reporting: Measuring Qualitative Characteristics. NiCE Working Paper 09-108.

Wang, C. L., \& Ahmed, P. K. (2007). Dynamic Capabilities: a Review and Research Agenda. The International Journal of Management Reviews, 9(1), 31-51.

Wang, \& Strong. (1996). Beyond Accuracy: What Data Quality Means to Data Consumers. Journal of Management Information Systems, 12(4), 5-33.

Widyastuti, N. M. A., Sujana, E., \& Adiputra, I. M. P. (2015). Analisis Kesiapan Pemerintah Daerah Dalam Menerapkan Standar Akuntansi Pemerintahan Berbasis Akrual di Kabupaten Gianyar. E-Journal SI Ak Universitas Pendidikan Ganesha, 3(1).

Zollo, M., \& Winter, S. G. (2002). Deliberate Learning and the Evolution of Dynamic Capabilities. Organization Science, 113, 339-351. 


\title{
LAMPIRAN:
}

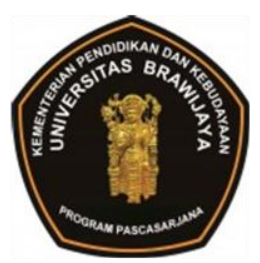

\author{
PROGRAM PASCA SARJANA \\ FAKULTAS EKONOMI DAN BISNIS \\ UNIVERSITAS BRAWIJAYA
}

Jl. Mayjen Haryono 165 Malang 65145 Telp. (0341) 561254

E-mail: pm-febub@fe.unibraw.ac.id http://www.fe.unibraw.ac.id

Kepada Yth. Bapak/lbu

di Tempat

Dengan hormat,

Saya adalah YP. Bondan Setiawan mahasiswa S2 jurusan Akuntansi pada FEB-UB. Dalam rangka penelitian tesis saya dengan judul "Pengaruh Parsial dari Dimensi Kapabilitas Dinamis terhadap Implementasi SAP dan dampaknya terhadap Kualitas Laporan Keuangan SKPD", maka dengan hormat saya mohon kesediaan Bapak/lbu selaku Pejabat Penatausaha Keuangan (PPK) dan staf yang membantu PPK secara langsung dalam melaksanakan kegiatan akuntansi untuk dapat berpartisipasi memberikan pendapat atas 39 (tiga puluh sembilan) pernyataan inti dan 6 (enam) pertanyaan profil responden yang ada dalam kuesioner ini. Kesediaan dan kerja sama yang Bapak/lbu dalam bentuk informasi yang benar dan lengkap akan sangat mendukung keberhasilan penelitian ini.

1. Pengumpulan data ini semata-mata hanya akan digunakan untuk maksud penyusunan tesis dan akan dijamin kerahasiaannya.

2. Semua pertanyaan di bawah terkait dengan kegiatan akuntansi SKPD.

3. Bapak/lbu cukup memberikan tanda silang (X) atau centang (V) pada pilihan jawaban yang telah disediakan berdasarkan persepsi yang Bapak/lbu pilih sesuai dengan kondisi kerja yang ada.

4. Kejujuran jawaban Bapak/lbu sangat kami harapkan.

Akhir kata saya mengucapkan terima kasih yang sebesar-besarnya atas bantuan dan kesediaan Bapak/lbu yang telah meluangkan waktunya dalam pengisian kuesioner ini. Apabila nanti Bapak/lbu memerlukan hasil penelitian ini, Bapak/lbu dapat menghubungi saya di HP 081-331-166-997 atau email: bondansetiawan@yahoo.com

Hormat saya,

\section{YP. Bondan Setiawan}

Diserahkan tgl

Diambil tgl 


\section{PETUNJUK PENGISIAN}

Alternatif jawaban terdiri atas 7 (tujuh) pilihan, mulai (1) Sangat Tidak Setuju, (2) Tidak Setuju, (3) Agak Tidak Setuju, (4) Netral, (5) Agak Setuju, (6) Setuju, dan (7) Sangat Setuju.

\section{KAPABILITAS PENGINDERAAN}

Menunjukkan kemampuan untuk mengidentifikasi, menginterpretasikan dan mendapatkan kesempatan yang ada pada lingkungan eksternal disekitarnya.

\begin{tabular}{|c|l|l|l|l|l|l|l|l|}
\hline No. & \multicolumn{1}{|c|}{ Pernyataan } & 1 & $\mathbf{2}$ & $\mathbf{3}$ & $\mathbf{4}$ & $\mathbf{5}$ & $\mathbf{6}$ & $\mathbf{7}$ \\
\hline 1 & $\begin{array}{l}\text { SKPD kami sering mengamati lingkungan untuk } \\
\text { mengenali peluang dalam pengembangan jenis } \\
\text { pekerjaan. }\end{array}$ & $\begin{array}{l}\text { SKPD kami secara rutin mengulas dampak yang } \\
\text { mungkin terjadi akibat dari perubahan lingkungan } \\
\text { kerja kami. }\end{array}$ & $\begin{array}{l}\text { SKPD kami sering mengulas upaya } \\
\text { pengembangan jenis pekerjaan untuk } \\
\text { memastikan bahwa upaya tersebut sejalan } \\
\text { dengan harapan masyarakat. }\end{array}$ \\
\hline 4 & $\begin{array}{l}\text { SKPD kami mencurahkan banyak waktu untuk } \\
\text { menerapkan ide demi mengembangkan pekerjaan } \\
\text { dan meningkatkan kualitas pekerjaan yang sudah } \\
\text { ada. }\end{array}$ & & & & & & \\
\hline
\end{tabular}

\section{KAPABILITAS BELAJAR}

Menunjukkan kemampuan untuk menemukan solusi, menciptakan pengetahuan baru, dan menyusun ulang kapabilitas operasional dalam mengembangkan pelayanan baru dan yang sudah ada.

\begin{tabular}{|c|c|c|c|c|c|c|c|c|}
\hline No. & Pernyataan & 1 & 2 & 3 & 4 & 5 & 6 & 7 \\
\hline 1 & $\begin{array}{l}\text { SKPD kami memiliki rutinitas yang efektif untuk } \\
\text { mengenali, menilai, dan memasukkan informasi } \\
\text { dan pengetahuan baru. }\end{array}$ & & & & & & & \\
\hline 2 & $\begin{array}{l}\text { SKPD kami memiliki rutinitas yang cukup untuk } \\
\text { menanamkan informasi dan pengetahuan baru. }\end{array}$ & & & & & & & \\
\hline 3 & $\begin{array}{l}\text { SKPD kami efektif dalam mengubah informasi } \\
\text { yang sudah ada menjadi pengetahuan baru. }\end{array}$ & & & & & & & \\
\hline 4 & $\begin{array}{l}\text { SKPD kami efektif untuk memanfaatkan } \\
\text { pengetahuan dalam pekerjaan baru. }\end{array}$ & & & & & & & \\
\hline 5 & $\begin{array}{lcr}\text { SKPD kami } & \text { efektif dalam mengembangkan } \\
\text { pengetahuan } & \text { baru yang } & \text { berpotensi } \\
\text { mempengaruhi } & \text { pengembangan } & \text { jenis/ragam } \\
\text { pekerjaan. }\end{array}$ & & & & & & & \\
\hline
\end{tabular}




\section{KAPABILITAS INTEGRASI}

Menunjukkan kemampuan dalam menyatukan pengetahuan baru ke dalam rutinitas operasional melalui penciptaan pemahaman bersama dan pemikiran kolektif.

\begin{tabular}{|c|l|l|l|l|l|l|l|l|}
\hline No. & \multicolumn{1}{|c|}{ Pernyataan } & 1 & 2 & 3 & 4 & 5 & $\mathbf{6}$ & $\mathbf{7}$ \\
\hline 1 & $\begin{array}{l}\text { Anggota SKPD kami siap dan sedia memberikan } \\
\text { masukan individu untuk kebutuhan kelompok. }\end{array}$ & & & & & & & \\
\hline 2 & $\begin{array}{l}\text { Anggota SKPD kami memiliki pemahaman global } \\
\text { tentang tugas dan tanggung jawab kami masing- } \\
\text { masing. }\end{array}$ & & & & & & & \\
\hline 3 & $\begin{array}{l}\text { Anggota SKPD kami tahu benar siapa orang } \\
\text { dalam kelompok kami yang memiliki kemampuan } \\
\text { khusus dan pengetahuan yang relevan dengan } \\
\text { pekerjaan kami. }\end{array}$ & $\begin{array}{l}\text { Anggota SKPD kami secara berhati-hati } \\
\text { menghubungkan tindakan kami dengan tindakan } \\
\text { orang lain agar dapat mengatasi kondisi yang } \\
\text { senantiasa berubah. }\end{array}$ & & & & & & \\
\hline 5 & $\begin{array}{l}\text { Para pegawai SKPD kami mampu mengaitkan } \\
\text { kegiatan-kegiatan mereka dengan baik. }\end{array}$ & & & & & & \\
\hline
\end{tabular}

\section{KAPABILITAS KOORDINASI}

Menunjukkan kemampuan dalam mengatur dan membagi tugas dengan baik, mendistribusikan sumber daya dan aktivitas secara merata.

\begin{tabular}{|c|l|l|l|l|l|l|l|l|}
\hline No. & \multicolumn{1}{|c|}{ Pernyataan } & $\mathbf{1}$ & $\mathbf{2}$ & $\mathbf{3}$ & $\mathbf{4}$ & $\mathbf{5}$ & $\mathbf{6}$ & $\mathbf{7}$ \\
\hline 1 & $\begin{array}{l}\text { SKPD kami memastikan agar hasil kerja kami } \\
\text { selaras dengan hasil kerja orang lain. }\end{array}$ & & & & & & \\
\hline 2 & $\begin{array}{l}\text { SKPD kami memastikan agar sumber daya } \\
\text { (misalnya, informasi, waktu, laporan) dialokasikan } \\
\text { dengan tepat dalam kelompok kami. }\end{array}$ & & & & & & & \\
\hline 3 & $\begin{array}{l}\text { Para pegawai SKPD kami ditunjuk untuk } \\
\text { melakukan tugas yang setara dengan } \\
\text { pengetahuan dan kemampuan yang terkait } \\
\text { dengan tugas mereka. }\end{array}$ \\
\hline 4 & $\begin{array}{l}\text { SKPD kami memastikan bahwa ada kesesuaian } \\
\text { antara keahlian anggota kelompok dengan proses } \\
\text { kerja mereka. }\end{array}$ & & & & & & & \\
\hline
\end{tabular}




\section{IMPLEMENTASI SAP}

Menunjukkan sejauh mana tujuan penerapan SAP yang direncanakan telah tercapai seperti yang diinginkan.

\begin{tabular}{|c|c|c|c|c|c|c|c|c|}
\hline No. & Pernyataan & 1 & 2 & 3 & 4 & 5 & 6 & 7 \\
\hline 1 & $\begin{array}{l}\text { SKPD kami telah sepenuhnya mencatat } \\
\text { pendapatan, beban, aset, utang dan ekuitas } \\
\text { dalam pelaporan finansial. }\end{array}$ & & & & & & & \\
\hline 2 & $\begin{array}{l}\text { SKPD kami telah menyusun laporan tentang } \\
\text { informasi posisi dan perubahan posisi sumber } \\
\text { daya ekonomi, kewajiban dan ekuitas pemerintah } \\
\text { (Neraca). }\end{array}$ & & & & & & & \\
\hline 3 & $\begin{array}{l}\text { SKPD kami telah menyusun informasi mengenai } \\
\text { sumber, alokasi, dan penggunaan sumber daya } \\
\text { ekonomi (LRA) yang dapat digunakan untuk } \\
\text { mengetahui ketaatan realisasi terhadap } \\
\text { anggarannya. }\end{array}$ & & & & & & & \\
\hline 4 & $\begin{array}{l}\text { SKPD kami telah menyusun laporan beban akrual } \\
\text { yang dapat digunakan untuk menghitung biaya } \\
\text { per program/ kegiatan pelayanan, dan juga } \\
\text { memprediksi pendapatan sehingga bisa } \\
\text { mengevaluasi kinerja pemerintahan daerah (LO). }\end{array}$ & & & & & & & \\
\hline 5 & $\begin{array}{l}\text { SKPD kami telah menyusun laporan informasi } \\
\text { kenaikan atau penurunan ekuitas tahun pelaporan } \\
\text { dibandingkan dengan tahun sebelumnya (LPE). }\end{array}$ & & & & & & & \\
\hline 6 & $\begin{array}{l}\text { SKPD kami telah mengakui dan mencatat aset, } \\
\text { kewajiban, dan ekuitas pada saat terjadi } \\
\text { transaksi, atau pada saat kejadian atau kondisi } \\
\text { lingkungan yang berpengaruh pada keuangan } \\
\text { pemerintah, tanpa memperhatikan saat kas atau } \\
\text { setara kas diterima atau dibayar. }\end{array}$ & & & & & & & \\
\hline 7 & $\begin{array}{l}\text { SKPD kami telah mengakui pendapatan-LO } \\
\text { dan/atau beban pada saat hak dan/atau } \\
\text { kewajiban untuk memperoleh pendapatan } \\
\text { dan/atau penurunan nilai kekayaan bersih telah } \\
\text { terpenuhi walaupun kas belum diterima di } \\
\text { rekening kas umum daerah. }\end{array}$ & & & & & & & \\
\hline 8 & $\begin{array}{l}\text { SKPD kami telah menyajikan aset sebesar biaya } \\
\text { perolehan apabila diperoleh dengan pembelian; } \\
\text { sebesar harga pokok produksi apabila diproduksi } \\
\text { sendiri; dan sebesar nilai wajar, apabila diperoleh } \\
\text { dengan cara lainnya. }\end{array}$ & & & & & & & \\
\hline 9 & $\begin{array}{l}\text { SKPD kami telah menyajikan kewajiban sebesar } \\
\text { nilai nominalnya atau sebesar jumlah yang belum } \\
\text { dibayarkan/disetorkan. }\end{array}$ & & & & & & & \\
\hline 10 & $\begin{array}{l}\text { SKPD kami telah menilai persediaan dengan } \\
\text { metode FIFO/rata-rata tertimbang/harga } \\
\text { pembelian terakhir apabila nilainya tidak material. }\end{array}$ & & & & & & & \\
\hline
\end{tabular}




\section{KUALITAS LAPORAN KEUANGAN}

Menunjukkan kecukupan dan transparansi informasi keuangan yang disajikan secara relevan dan andal agar tidak menyesatkan pengguna laporan keuangan.

\begin{tabular}{|c|c|c|c|c|c|c|c|c|}
\hline No. & $\begin{array}{l}\text { Pernyataan } \\
\end{array}$ & 1 & 2 & 3 & 4 & 5 & 6 & 7 \\
\hline 1 & $\begin{array}{l}\text { Laporan keuangan SKPD kami mengandung } \\
\text { informasi yang memungkinkan pengguna untuk } \\
\text { menegaskan atau mengoreksi ekspektasi mereka } \\
\text { di masa lalu. }\end{array}$ & & & & & & & \\
\hline 2 & $\begin{array}{l}\text { Laporan keuangan SKPD kami dapat membantu } \\
\text { dalam memperkirakan aktivitas yang } \\
\text { berhubungan dengan keuangan pada periode } \\
\text { berikutnya. }\end{array}$ & & & & & & & \\
\hline 3 & $\begin{array}{l}\text { Laporan keuangan SKPD kami tidak dapat } \\
\text { membantu dalam pengambilan keputusan. }\end{array}$ & & & & & & & \\
\hline 4 & $\begin{array}{l}\text { Laporan keuangan SKPD kami secara rutin } \\
\text { disajikan tepat waktu. }\end{array}$ & & & & & & & \\
\hline 5 & $\begin{array}{l}\text { Laporan keuangan SKPD kami telah menyajikan } \\
\text { semua informasi akuntansi yang dapat } \\
\text { mempengaruhi pengambilan keputusan. }\end{array}$ & & & & & & & \\
\hline 6 & $\begin{array}{l}\text { Informasi dalam laporan keuangan SKPD kami } \\
\text { telah menggambarkan secara jujur semua } \\
\text { transaksi dan peristiwa lainnya yang seharusnya } \\
\text { disajikan. }\end{array}$ & & & & & & & \\
\hline 7 & $\begin{array}{l}\text { Informasi yang disajikan dalam laporan keuangan } \\
\text { SKPD kami dapat diuji dengan baik. }\end{array}$ & & & & & & & \\
\hline 8 & $\begin{array}{l}\text { Laporan keuangan SKPD kami disajikan untuk } \\
\text { kebutuhan umum dan tidak berpihak pada pihak } \\
\text { tertentu. }\end{array}$ & & & & & & & \\
\hline 9 & $\begin{array}{l}\text { Setiap informasi dalam laporan keuangan SKPD } \\
\text { kami disertai dengan penjelasan yang rinci } \\
\text { sehingga kekeliruan dalam interpretasi dan } \\
\text { penggunaan informasi tersebut dapat dicegah. }\end{array}$ & & & & & & & \\
\hline 10 & $\begin{array}{l}\text { Seluruh informasi yang disajikan dalam laporan } \\
\text { keuangan SKPD kami dapat dipahami dengan } \\
\text { mudah. }\end{array}$ & & & & & & & \\
\hline 11 & $\begin{array}{l}\text { Informasi dalam laporan keuangan SKPD kami } \\
\text { dinyatakan dalam istilah yang mudah dipahami. }\end{array}$ & & & & & & & \\
\hline
\end{tabular}

